\title{
Kajian Model Pembelajaran Kooperatif Tipe STAD (Student Teams Achievement Division) Dalam Upaya Meningkatkan Efektifitas Proses Belajar Mengajar Akuntansi
}

\author{
${ }^{1}$ Yudho Ramafrizal Suryana, ${ }^{2}$ Teni Julia Somadi \\ 1 Universitas Pasundan, ${ }^{2}$ SMKN 3 Bandung \\ Email: yudhoramafrizal@unpas.ac.id
}

\begin{abstract}
ABSTRAC
The purpose of this research is to know how the result of applying Adjustment journal concept through cooperative learning model type STAD (Student Teams Achievement Division) in class XI IPS 3 SMAN 6 Bandung, to know how the effectiveness of teaching and learning process in accounting subjects subject of adjustment journal by using model STAD type cooperative learning, STAD type cooperative learning model (Student Teams Achievement Division) in order to overcome the saturation and difficulties experienced by students of class XI IPS 3 SMAN 6 Bandung. The research methodology used is descriptive research. The subjects of the study were students of class XI IPS 3 SMAN 6 Bandung. Data collection techniques in this study were conducted with documentation and questionnaire / questionnaire. The results of the application of STAD type cooperative learning model in the subject of adjusting journal shows 3.94 results that are in good category. the results of research from the effectiveness of teaching and learning process on the subjects of accounting showed 3.99 results are in either category. STAD type cooperative learning model in overcoming the saturation and learning difficulties learners showed the average result classical is 3.97 which is in good category and the level of effectiveness of teaching and learning process of $79.94 \%$ of the data obtained based on the questionnaire distributed to 36 respondents. Based on the findings in the field, the conclusion of the results of this study is STAD type cooperative learning model can overcome the saturation and learning difficulties faced by learners. Therefore this learning model can be used for learning so that teaching and learning process can be implemented effectively.
\end{abstract}

Keywords: Cooperative Learning, STAD Model, Effective Learning.

\section{PENDAHULUAN}

Manusia membutuhkan pendidikan dalam kehidupannya. A.L. Pradja (2008:24) menyatakan bahwa pendidikan merupakan usaha agar manusia dapat mengembangkan potensi dirinya melalui proses pembelajaran. Kegiatan pendidikan pada umumnya dilaksanakan disetiap jenjang pendidikan melalui kegiatan belajar mengajar. Proses belajar mengajar yang ada merupakan penentu keberhasilan dalam mencapai tujuan pendidikan. Peserta didik dan guru memiliki peranan penting dalam kegiatan belajar mengajar.

Pendidikan merupakan kunci untuk semua kemajuan dan perkembangan yang berkualitas, sebab dengan pendidikan manusia dapat mewujudkan semua potensi dirinya baik sebagai pribadi maupun sebagai warga masyarakat. Aspek proses pembelajaran merupakan salah satu penyebab perlunya ditingkatkan mutu pendidikan. Kualitas proses belajar mengajar yang rendah menunjukkan bahwa interaksi antara siswa dengan sumber belajar seperti dengan guru dan linkungan, tidak berjalan efektif sehingga hasil belajar yang dicapai tidak optimal (Purwanti, 2004). Oleh karena itu dalam proses pembelajaran diupayakan agar lingkungan belajar dapat mendukung berlangsungnya pembelajaran efektif dan berpusat pada siswa dan guru. Syamsulbachri (2006:97) menyatakan ada beberapa faktor yang harus diperhatikan dalam rangka meningkatkan nilai efektifitas kegiatan mengajar dalam suatu lingkungan belajar yaitu:

1. Tujuan yang ingin dicapai 
2. Faktor siswa

3. Faktor guru

4. Faktor sifat dan materi yang akan disajukan

5. Faktor dana atau fasilitas yang tersedia

6. Faktor waktu yang tersedia bagi pelaksana PBM

Berdasarkan hasil observasi keadaan siswa kelas XI IPS 3 di SMAN 6 Bandung ditemukan fenomena efektivitas proses belajar mengajar, seperti yang ditunjukan pada tabel berikut ini.

Tabel 1

Hasil Kuisioner Pelaksanaan Proses Belajar Mengajar Mata Pelajaran Akuntansi

\begin{tabular}{clccc}
\hline No & \multicolumn{1}{c}{ Pertanyaan } & S & KK & TS \\
\hline 1 & $\begin{array}{l}\text { Saya sering merasa jenuh dan mengantuk pada saat } \\
\text { belajar akuntansi dengan menggunakan metode } \\
\text { ceramah }\end{array}$ & $85 \%$ & $10 \%$ & $5 \%$ \\
\hline 2 & $\begin{array}{l}\text { Materi yang diajarkan menggunakan metode } \\
\text { ceramah kurang dipahami }\end{array}$ & $75 \%$ & $20 \%$ & $5 \%$ \\
\hline 3 & $\begin{array}{l}\text { Saya lebih senang belajar kelompok dan diskusi dari } \\
\text { pada belajar sendiri }\end{array}$ & $80 \%$ & $10 \%$ & $10 \%$ \\
\hline 4 & $\begin{array}{l}\text { Mempunyai tim belajar (kelompok belajar) membuat } \\
\text { saya rajin belajar }\end{array}$ & $70 \%$ & $5 \%$ & $25 \%$ \\
\hline 5 & $\begin{array}{l}\text { Sering mengobrol ketika pembelajaran dengan } \\
\text { menggunakan metode ceramah }\end{array}$ & $55 \%$ & $30 \%$ & $15 \%$ \\
\hline
\end{tabular}

Sumber: hasil observasi di SMAN 6 Bandung

Berdasarkan tabel di atas, diketahui bahwa kegiatan proses belajar mengajar di latarbelakangi oleh peserta didik yang merasa jenuh dan mengantuk dengan proses belajar mengajar yang hanya menggunakan metode ceramah, materi yang disampaikanpun kurang dipahami sehingga menimbulkan kurangnya efektivitas proses belajar mangajar. Peserta didik lebih senang belajar berkelompok dari pada belajar sendiri. Kendala yang dihadapi peserta didik dalam pembelajaran akuntansi yaitu dalam menentukan akun-akun yang harus disesuaikan kurang dapat dipahami peserta didik yang disebabkan kurang kebersamaan di antara peserta didik yang sudah mengerti untuk memberikan pengetahuannya pada peserta didik yang kurang paham untuk menciptakan kebersamaan diantara peserta didik diperlukan model pembelajaran yang mengharuskan peserta didik untuk bekerja dalam suatu tim untuk menyelesaikan masalah, menyelesaikan tugas, atau mengerjakan sesuatu untuk tujuan bersama.

Dalam upaya meningkatkan efektifitas proses belajar mengajar mata pelajaran akuntansi diperlukan proses pemilihan model pembelajaran yang digunakan bagi pelaksanaan proses belajar mengajar. Dalam hal ini, Model pembelajaran kooperatif merupakan model pembelajaran yang mampu menciptakan kesempatan siswa berinteraksi, bekerjasama secara gotong royong untuk meningkatkan pemahaman yang lebih tinggi yang dapat meningkatkan hasil belajar dalam Rochyadi, (2000: 6). Disamping itu, model pembelajaran kooperatif menurut Rochyadi akan meningkatkan hubungan yang lebih positif antar siswa dan suasana belajar lebih menyenangkan.

Dalam pembelajaran kooperatif dibutuhkan kerjasama yang baik agar karya yang dihasilkan maksimal. Hal ini tidak mudah diwujudkan karena dibutuhkan kesadaran dari setiap individu dalam kelompok. Dalam perkembangan pembelajaran kooperatif terdapat teknik pembelajaran kooperatif yang membentuk suatu kelas menjadi beberapa kelompok kecil yang setiap kelompoknya terdiri dari beberapa siswa. Kelompok kecil ini akan berdiskusi bersama dalam memecahkan permasalahan yang diberikan oleh guru.

Salah satu tipe dari teknik pembelajaran kooperatif adalah teknik kooperatif tipe STAD (Student Teams Achievement Division) merupakan salah satu metode atau pendekatan dalam pembelajaran kooperatif yang sederhana dan baik untuk guru yang baru 
mulai menggunakan pendekatan kooperatif dalam kelas, STAD juga merupakan suatu model pembelajaran kooperatif yang efektif. Untuk itu, dalam penelitian ini akan menguji apakah model pembelajaran kooperatif tipe STAD (Student Teams Achievement Division) dapat mengatasi kejenuhan dan kesulitan yang dialami oleh peserta didik kelas XI IPS 3 SMAN 6 Bandung

\section{LANDASAN TEORI}

\section{Model Pembelajaran Kooperatif}

Pembelajaran yang bernaung dalam teori konstruktivis adalah kooperatif. Pembelajaran kooperatif muncul dari konsep bahwa siswa akan lebih mudah menemukan dan memahami konsep yang sulit jika mereka saling berdiskusi dengan temannya. Menurut Trianto (2007:42) menyatakan bahwa pembelajaran kooperatif merupakan sebuah kelompok strategi pengajaran yang melibatkan siswa bekerja secara berkolaborasi untuk mencapai tujuan bersama.

Menurut Gunawan (2011:31), menyatakan bahwa model pembelajaran kooperatif merupakan salah satu model pembelajaran yang mendukung pembelajaran konstektual. Sistem pengajaran cooperative learning dapat didefinisikan sebagai sistem kerja/belajar kelompok yang terstruktur. Menurut Suprijono (2012:54), menyatakan bahwa model pembelajaran kooperatif adalah konsep yang lebih luas meliputi semua jenis kerja kelompok termasuk bentuk-bentuk yang lebih dipimpin oleh guru atau diarahkan oleh guru. Dari pengertian diatas maka dapat dinyatakan bahwa pembelajaran kooperatif merupakan strategi belajar dengan sejumlah siswa sebagai anggota kelompok kecil yang tingkat kemampuannya berbeda. dalam menyelesaikan tugas kelompoknya, setiap siswa anggota kelompok harus saling bekerja sama dan saling membantu untuk memahami materi pelajaran.

Menurut Trianto, (2007: 48) terdapat 6 langkah utama dalam menerapkan model pembelajaran kooperatif yaitu:

a. Guru menyampaikan semua tujuan pembelajaran yang ingin dicapai dalam mata pelajaran yang dipelajari dan memberikan motivasi belajar kepada peserta didik

b. Guru menyampaikan informasi kepada peserta didik dengan demonstrasi (peragaan)

c. Siswa dikelompokkan dalam kelompok-kelompok belajar

d. Bimbingan kelompok-kelompok belajar pada saat siswa mengerjakan tugas

e. Setiap akhir pembelajaran guru mengadakan evaluasi untuk mengetahui penguasaan materi pelajaran oleh peserta didik yang telah dipelajari.

f. Guru memberikan penghargaan untuk menghargai upaya dan hasil belajar individu maupun kelompok.

\section{Model Pembelajaran STAD (Student Teams Achievment Division)}

Menurut Slavin (2010:143) model pembelajaran STAD merupakan salah satu metode pembelajaran kooperatif yang paling sederhana, dikatakan demikian karena kegiatan pembelajaran yang dilakukan masih dekat kaitannya dengan pembelajaran konvensional. Model ini merupakan model yang paling baik untuk permulaan bagi para guru yang baru menggunakan pendekatan kooperatif. Guru yang menggunakan metode STAD mengacu kepada belajar kelompok peserta didik dan menyajikan informasi akademik baru kepada peserta didik setiap minggunya yang menggunakan persentasi variabel dan teks. Peserta didik dalam suatu kelas tertentu dipecah menjadi kelompok dengan anggota 4-5 orang. Setiap kelompok haruslah heterogen, terdiri dari laki-laki dan perempuan, berasal dari berbagai suku, memiliki kemampuan tinggi, sedang dan rendah.

Menurut Ibrahim dalam Rinawati, (2002:4) menyatakan bahwa Model pembelajaran STAD (Student Team Achivement Division) merupakan salah satu bentuk dari model cooperative learning yang paling sederhana, yang dikembangkan setidak-tidaknya untuk 
mencapai tiga tujuan pembelajaran penting, yaitu hasil belajar akademik siswa yang meningkat, peranan terhadap keragaman, dan pengembangan keterampilan sosial.

Trianto (2007:52) menyatakan bahwa pembelajaran kooperatif tipe STAD ini merupakan salah satu tipe dari model pembelajaran kooperatif dengan menggunakan kelompok-kelompok kecil dengan jumlah anggota tiap kelompok 4-5 orang siswa secara heterogen. Dari pengertian di atas dapat dinyatakan bahwa model pembelajaran kooperatif tipe STAD merupakan suatu model pembelajaran kooperatif yang diterapkan dalam proses pembelajaran di kelas, pembelajaran menggunakan kelompok-kelompok dengan jumlah anggota kelompok 4-5 orang siswa secara heterogen. Model STAD lebih mementingkan sikap partisipasi peserta didik dalam rangka mengembangkan potensi kognitif dan afektif kelebihan STAD ini, antara lain sebagai berikut :

1) Relatif mudah menyelenggarakannya.

2) Mampu memotivasi peserta didik dalam mengembangkan potensi individu terutama kreatifitas dan tanggungjawab dalam mengangkat citra kelompoknya.

3) Melatih peserta didik untuk bekerja sama dan saling tolong dalam kelompok.

4) Peserta didik mampu meyakinkan dirinya dan orang lain bahwa tujuan yang ingin dicapai bergantung pada kinerja mereka, bukanlah karena keberuntungan

5) Peserta didik lebih mampu berkomunikasi verbal dan nonverbal dalam bekerjasama.

6) Meningkatkan keakraban peserta didik.

Menurut slavin, (2010:143) penerapan metode STAD terdiri dari lima komponen utama pembelajaran yang membawa peserta didik pada suasana kerja sama yaitu sebagai berikut:

1) Presentasi Kelas

Presentasi merupakan salah satu jenis pengajaran dalam kelas. Presentasi merupakan komunikasai satu arah, dimana informasi disampaikan kepada audiens oleh pembicara.

2) Kerja Kelempok (tim)

Kerja kelompok atau belajar kelompok merupakan salah satu kegiatan dalam belajar yang dilakukan bersama-sama dengan masing-masing tugas-tugas. Tugas anggota kelompok adalah menguasai materi yang diberikan guru dan membantu teman satu kelempok untuk menguasai materi tersebut. Siswa diberi lembar kegiatan yang dapat digunakan untuk melatih keterampilan yang sedang diajarkan untuk mengevaluasi diri mereka dan teman satu kelompok.

3) Kuis

Kuis dikerjakan siswa secara mandiri. Tujuannya untuk menunjukkan apa saja yang telah diperoleh siswa selama belajar dalam kelompok. Hasil kuis digunakan sebagai nilai perkembangan individu dan disumbangkan dalam nilai kelompok.

4) Skor Kemajuan individu

Merupakan nilai dari hasil-hasil kuis yang diadakan dalam belajar kelempok atau tes cepat setelah guru menjelaskan suatu materi. Hasil-hasil nilai tsb bisa menambah nilai secara pribadi yang nantinya dapat memberikan kontribusi poin yang maksimal kepada tim nya dalam sistem skor ini.

5) Rekognisi tim

Pemberian penghargaan kelompok (tim) berdasarkan pada rata-rata nilai perkembangan individu. Diambil dari nilai hasil individu yang dikelompokan dengan hasil kerja kelompok maka akan didapat nilai kelompok sehingga bisa diberikan sebuah penghargaan kelompok terbaik. Tim akan mendapatkan sertifikat atau bentuk penghargaan yang lain apabila skor rata-rata mereka mencapai kriteria tertentu.

Penghargaan atas keberhasilan kelompok (tim) dapat dilakukan oleh guru dengan melakukan tahapan-tahapan sebagai berikut:

1) Menghitung skor individu

Menurut Slavin (2010:159) untuk memberikan skor perkembangan individu dihitung seperti pada tabel berikut ini: 


\section{Nilai Perkembangan Skor Individu}

\begin{tabular}{lll}
\hline No & \multicolumn{1}{c}{ Skor Siswa } & Nilai Perkembangan \\
\hline 1. & $\begin{array}{l}\text { Lebih dari 10 point di bawah skor } \\
\text { dasar }\end{array}$ & 5 \\
2. & $\begin{array}{l}10 \text { point hingga 1 point dibawah } \\
\text { skor dasar }\end{array}$ & 10 \\
3. $\quad \begin{array}{l}\text { Skor dasar sampai 10 point } \\
\text { diatasnya }\end{array}$ & 20 \\
4. $\quad \begin{array}{l}\text { Lebih dari 10 point diatas skor } \\
\text { dasar }\end{array}$ & 30 \\
\hline Kertas jawaban sempurna (terlepas dari skor awal) 30 \\
\hline Sumber: Slavin (2010:159)
\end{tabular}

2) Menghitung skor kelompok

Skor ini dihitung dengan membuat rata-rata skor perkembangan anggota kelompok, yaitu dengan jumlah skor perkembangan yang diperoleh anggota kelompok dibagi dengan jumlah anggota kelompok. Sesuai dengan rata-rata perkembangan kelompok, diperoleh kategori skor kelompok seperti tercantum pada tabel berikut ini:

Tabel 3

Tingkat Penghargaan Kelompok

\begin{tabular}{ll}
\hline Rata-Rata Kelompok & Penghargaan \\
\hline 15 Point & Tim baik \\
25 Point & Tim hebat \\
30 Point & Tim super \\
\hline
\end{tabular}

Sumber: Trianto (2007:56)

\section{Efektivitas Proses Belajar Mengajar}

Pengajaran merupakan hasil proses belajar mengajar, efektivitasnya tergantung dari beberapa unsur. Efektivitas suatu kegiatan tergantung dari terlaksana tidaknya perencanaan. Karena perencanaan maka pelaksanaan pengajaran menjadi baik dan efektif. Menurut Abdurahmat (2003:92) dalam Http://lbnuNeoBlog'z/2012/03/20, efektifitas adalah pemanfaatan sumber daya, sarana dan prasarana dalam jumlah tertentu yang secara sadar ditetapkan sebelumnya untuk menghasilkan sejumlah pekerjaan tepat pada waktunya. Menurut Tim Pembina Mata Kuliah Didaktik Metodik/Kurikulum IKIP Surabaya dalam Suryosubroto (2010:7), menyatakan bahwa:

Efisiensi dan efektivitas mengajar dalam proses interaksi belajar mengajar yang baik adalah segala daya upaya guru untuk membantu peserta didik agar bisa belajar dengan baik. Untuk mengetahui efektivitas mengajar, dengan memberikan tes sebagai hasil tes dapat dipakai untuk mengevaluasi berbagai aspek proses pengajaran. Hasil tes mengungkapkan kelemahan belajar siswa dan kelemahan pengajar secara menyeluruh.

Dari pengertian di atas dapat dinyatakan bahwa efektifitas merupakan pemanfaatan suatu kegiatan yang tergantung dari terlaksana tidaknya suatu perencanaan. Menurut L.I Pasaribu dan B. Simanjuntak, dalam Suryosubroto, (2010:8), menyatakan pendidikan efektifitas dapat ditinjau dari dua segi, yaitu:

1) Mengajar guru, dimana menyangkut sejauh mana kegiatan belajar mengajar yang direncanakan terlaksana.

2) Belajar murid, yang menyangkut sejauh mana tujuan pelajaran yang diinginkan tercapai melalui kegiatan belajar mengajar.

Pada hakikatnya mengajar adalah melakukan kegiatan belajar, sehingga proses belajar mengajar berlangsung secara efektif dan efisien. Dalam pelaksanaan proses belajar 
mengajar di sekolah, seorang guru dalam mengajar harus memiliki kemampuan yang baik, agar kegiatan belajar mengajar dapat efektif.

Proses belajar mengajar merupakan inti dari kegiatan pendidikan di sekolah. Proses belajar mengajar hendaknya mengikut sertakan peserta didik secara aktif guna mengembangkan kemampuan-kemampuan peserta didik. . Menurut Ibrahim (2003:30), proses belajar mengajar adalah Proses belajar mengajar merupakan dua hal yang berbeda tetapi membentuk satu kesatuan, ibarat sebuah mata uang bersisi dua. Belajar merupakan kegiatan yang dilakukan oleh siswa sedangkan mengajar adalah kegiatan yang dilakukan oleh guru sangat mempengaruhi kegiatan belajar siswa. Agar pelaksanaan pengajaran berjalan efisien dan efektif, maka diperlukan perencanaan yang tersusun secara sistematis dengan proses belajar mengajar yang lebih bermakna dan mengaktifkan siswa serta dirancang dalam satu scenario yang jelas.

Proses belajar mengajar dinyatakan pula oleh Moch. Uzer Usman dalam Suryosubroto (2009:16) dengan mendinisikan proses belajar mengajar sebagai berikut Proses belajar mengajar adalah suatu proses yang mengandung serangkaian perbuatan guru dan peserta didik atas dasar hubungan timbal balik yang berlangsung dalam situasi edukatif untuk mencapai tujuan tertentu.

Dalam buku Pedoman Guru Pendidikan Agama Islam terbitan Depag RI dalam Suryosubroto, (2009:16) menyatakan bahwa Proses belajar mengajar adalah sebagai proses dapat mengandung dua pengertian, yaitu rentetan tahapan atau fase dalam mempelajari sesuatu dan dapat pula berarti sebagai rentetan kegiatan perencanaan oleh guru, pelaksanaan kegiatan sampai evaluasi dan program tidak lanjut.

Dari pendapat-pendapat tersebut penulis dapat menyatakan bahwa proses belajar mengajar meliputi kegiatan yang dilakukan guru mulai dari perencanaan, pelaksanaan kegiatan sampai evaluasi dan program tindak lanjut yang berlangsung dalam situasi edukatif untuk mencapai tujuan tertentu yaitu pengajaran. Dengan perencanaan maka pelaksanaan pengajaran menjadi baik dan efektif yaitu murid harus dijadikan pedoman setiap kali membuat persiapan mengajar. Proses belajar mengajar merupakan inti dari proses pendidikan formal dengan guru sebagai pemegang peranan utama. Dalam proses belajar mengajar sebagian besar hasil belajar peserta didik ditentukan oleh peranan guru. Guru yang kompeten mampu menciptakan lingkungan belajar yang efektif dan akan lebih mampu mengelola proses belajar mengajar sehingga hasil belajar siswa berada pada tingkat yang optimal.

\section{METODE PENELITIAN}

Dalam melakukan penelitian diperlukan suatu metode sebagai langkah-langkah yang harus ditempuh dalam memecahkan suatu permasalahan. Menurut Sugiyono (2010:2) menyatakan metode penelitian merupakan cara ilmiah yang digunakan untuk mendapatkan data dengan tujuan dan kegunaan tertentu.

Metode yang penulis gunakan dalam penelitian ini adalah metode penelitian Deskriptif. Menurut Arikunto (2006:209), menyatakan bahwa penelitian deskriptif merupakan penelitian non hipotesis sehingga dalam langkah penelitiannya tidak perlu merumuskan hipotesis. Populasi adalah siswa kelas XI IPS 3 SMAN 6 Bandung. Kelas XI IPS 3 dengan jumlah 36 yang terdiri dari 20 laki - laki dan 16 siswa perempuan sebagai informen, serta guru dan kepala sekolah sebagai key informen dalam penelitian ini. Teknik pengumpulan data yang dilakukan dalam penelitian ini adalah Kuisioner/Angket. Sedangkan analisis dilakukan menggunakan pendekatan statistik berikut:

1) Melakukan uji validitas

2) Melakukan Uji reliabilitas

Intrumen yang sudah dinyatakan valid dan reliabel, selanjutnya disebarkan kepada seluruh responden (sampel penelitian) untuk diisi sesuai dengan pendapatnya masingmasing. Setelah data terkumpul kemudian dilakukan pengolahan secara statistik dengan rumus sebagai berikut: 


$$
\bar{x}=\frac{\text { Jumlah rata-rata skor yang dicapai }}{\text { Jumlah pertanyaan }}
$$

Hasil perhitungan rata-rata kemudian ditafsirkan dengan kriteria sebagai beikut:

Tabel 4

\section{Kriteria Penafsiran Penerapan Koopratif tipe STAD dan Efektivitas} Proses Belajar Mengajar

\begin{tabular}{ccc}
\hline No & Rata-rata Skor & Penafsiran \\
\hline 1 & $0,00-0,82$ & Sangat buruk \\
2 & $0,83-1,66$ & Buruk \\
3 & $1,67-2,49$ & Kurang baik \\
4 & $2,50-3,32$ & Cukup Baik \\
5 & $3,33-4,16$ & Baik \\
6 & $4,17-5,00$ & Sangat baik/ideal
\end{tabular}

Sumber : Jurnal ilmiah Kependidikan FKIP UNPAS

\section{HASIL DAN PEMBAHASAN}

\section{Penerapan Model Pembelajaran Kooperatif tipe STAD Dalam Pokok Bahasan Jurnal Penyesuaian di Kelas XI IPS 3 SMAN 6 Bandung}

Pada proses pembelajaran dengan menerapkan model pembelajaran kooperatif tipe STAD, guru awalnya memberikan informasi tentang tugas belajar yang harus dikerjakan. Para guru yang menggunakan STAD umumnya membagi kelas menjadi beberapa kelompok yang beranggotakan 4 sampai 5 dengan karakteristik heterogen (Trianto 2007:52). Selanjutnya peserta didik memilih topik untuk diselidiki dan melakukan penyelidikan yang mendalam atas topik yang telah dipilih kemudian mempresentasikan laporannya di depan kelas. Sebagai acuan model ini guru menggunakan sumber slavin.

Menurut Slavin, (2010:143) penerapan metode STAD terdiri dari lima komponen utama pembelajaran yang membawa peserta didik pada suasana kerja sama yaitu sebagai berikut :

a. Presentasi Kelas

b. Kerja Kelompok (Tim)

c. Kuis

d. Skor Kemajuan individu

e. Rekognisi tim

Langkah-langkah tersebut dijadikan acuan oleh guru sebagai proses pengimplementasian model pembelajaran ini untuk melihat implementasi model pembelajaran kooperatif tipe STAD. Penghargaan atas keberhasilan kelompok (tim) dapat dilakukan oleh guru dengan melakukan tahapan-tahapan sebagai berikut:

\section{a. Menghitung skor individu}

\section{Tabel 5}

Daftar Skor Perkembangan Individu

\begin{tabular}{llccc}
\hline No & Nama Siswa & $\begin{array}{c}\text { Skor } \\
\text { Awal }\end{array}$ & $\begin{array}{c}\text { Skor } \\
\text { Kuis }\end{array}$ & $\begin{array}{c}\text { Poin } \\
\text { Kemajuan }\end{array}$ \\
\hline 1 & Abdhira Yusuf Paramandika & 65 & 70 & 10 \\
2 & Aditya Panjidanni & 85 & 90 & 10 \\
3 & Adityarachman & 60 & 70 & 20 \\
4 & Akmal Maulana & 60 & 70 & 20 \\
5 & Anisya Listi Supriadi & 85 & 90 & 10 \\
6 & Arasy Akbar Witarsa & 70 & 80 & 20 \\
7 & Arlin Oktavia & 85 & 90 & 10 \\
\hline
\end{tabular}




\begin{tabular}{|c|c|c|c|c|}
\hline No & Nama Siswa & $\begin{array}{l}\text { Skor } \\
\text { Awal }\end{array}$ & $\begin{array}{l}\text { Skor } \\
\text { Kuis }\end{array}$ & $\begin{array}{c}\text { Poin } \\
\text { Kemajuan }\end{array}$ \\
\hline 8 & Bella Holisoh & 75 & 90 & 30 \\
\hline 9 & Cindy Diah Apristi & 65 & 90 & 30 \\
\hline 10 & Dimas Muhamad & 65 & 70 & 10 \\
\hline 11 & Erik Samuel & 70 & 75 & 10 \\
\hline 12 & Fajar Trisna Adrian & 80 & 90 & 20 \\
\hline 13 & Fakhri Fauzan Tajudin & 60 & 65 & 10 \\
\hline 14 & Febiyana Wulandari & 85 & 95 & 20 \\
\hline 15 & Gilang Pratama Gandahutama & 65 & 70 & 10 \\
\hline 16 & Guntur Ibrahim & 85 & 90 & 10 \\
\hline 17 & Hanny Meilani & 85 & 95 & 20 \\
\hline 18 & Izmi Agista Noer Mauli & 65 & 60 & 5 \\
\hline 19 & Juhan Fitrian & 75 & 75 & - \\
\hline 20 & Ludi Rahadi Saputra & 70 & 80 & 20 \\
\hline 21 & Luly Ayu Sudiarti & 60 & 70 & 20 \\
\hline 22 & Luthfy Fatsyah & 60 & 70 & 20 \\
\hline 23 & M. Helmidzan A & 65 & 65 & - \\
\hline 24 & Mega Mulyani & 60 & 70 & 20 \\
\hline 25 & Mochamad Gilang Ramadhani & 60 & 65 & 10 \\
\hline 26 & Mohamad Rizky & 50 & 60 & 20 \\
\hline 27 & Muhamad Fajar K & 75 & 70 & 5 \\
\hline 28 & Nadia Oktavia & 85 & 95 & 20 \\
\hline 29 & Nia Kurniawati & 90 & 95 & 10 \\
\hline 30 & Rakhmanda Wijaksono & 60 & 80 & 30 \\
\hline 31 & Rena Ameliya & 90 & 95 & 10 \\
\hline 32 & Riki Andani & 60 & 90 & 30 \\
\hline 33 & Rina Nuraeni & 90 & 95 & 10 \\
\hline 34 & Rizky Nur Maulana & 75 & 80 & 10 \\
\hline 35 & Vira Firliana Oktaviani & 70 & 90 & 30 \\
\hline 36 & Yayu Sri Rahayu & 90 & 95 & 10 \\
\hline
\end{tabular}

Menurut Slavin (2010:159) untuk memberikan skor perkembangan individu dihitung seperti pada tabel berikut ini:

Tabel 6

Nilai Perkembangan Skor Individu

\begin{tabular}{llc}
\hline No & Skor Siswa & Nilai Perkembangan \\
\hline 1 & $\begin{array}{l}\text { Lebih dari 10 point di bawah skor } \\
\text { dasar }\end{array}$ & 5 \\
2 & $\begin{array}{l}10 \text { point hingga } 1 \text { point dibawah } \\
\text { skor dasar }\end{array}$ & 10 \\
3 & $\begin{array}{l}\text { Skor dasar sampai } 10 \text { point } \\
\text { diatasnya } \\
\text { Lebih dari } 10 \text { point diatas skor }\end{array}$ & 20 \\
dasar & 30 \\
\hline Kertas jawaban sempurna (terlepas dari skor awal) 30 \\
\hline Sumber: Slavin (2010:159)
\end{tabular}


b) Menghitung skor kelompok

Tabel 7

Klasifikasi Penghargaan Kelompok

\begin{tabular}{|c|c|c|c|c|c|}
\hline No & Nama Siswa & $\begin{array}{l}\text { Skor } \\
\text { Awal }\end{array}$ & $\begin{array}{l}\text { Skor } \\
\text { Kuis }\end{array}$ & $\begin{array}{c}\text { Poin } \\
\text { Kemajuan }\end{array}$ & Penghargaan \\
\hline \multicolumn{5}{|c|}{ Kelompok 1} & TIM HEBAT \\
\hline 1 & Nadia Oktavia & 85 & 95 & 20 & \\
\hline 2 & Ludi Rahadi Saputra & 70 & 80 & 20 & \\
\hline 3 & Rakhmanda Wijaksono & 60 & 80 & 30 & \\
\hline 4 & Riki Andani & 60 & 90 & 30 & \\
\hline \multicolumn{4}{|c|}{ Jumlah Rata-rata } & 25 & \\
\hline \multicolumn{5}{|c|}{ Kelompok 2} & \\
\hline 1 & Abdhira Yusuf $\mathrm{P}$ & 65 & 70 & 10 & \\
\hline 2 & Dimas Muhamad & 65 & 70 & 10 & \\
\hline 3 & Nia Kurniawati & 90 & 95 & 10 & \\
\hline 4 & Luly Ayu Sudiarti & 60 & 70 & 20 & \\
\hline \multicolumn{4}{|c|}{ Jumlah Rata-rata } & 12,5 & \\
\hline \multicolumn{5}{|c|}{ Kelompok 3} & TIM BAIK \\
\hline 1 & Adityarachman & 60 & 70 & 20 & \\
\hline 2 & Rena Ameliya & 90 & 95 & 10 & \\
\hline 3 & Yayu Sri Rahayu & 90 & 95 & 10 & \\
\hline 4 & Luthfy Fatsyah & 60 & 70 & 20 & \\
\hline \multicolumn{4}{|c|}{ Jumlah Rata-rata } & 15 & \\
\hline \multicolumn{5}{|c|}{ Kelompok 4} & TIM BAIK \\
\hline 1 & Akmal Maulana & 60 & 70 & 20 & \\
\hline 2 & Anisya Listi Supriadi & 85 & 90 & 10 & \\
\hline 3 & Cindy Diah Apristi & 65 & 90 & 30 & \\
\hline 4 & Rizky Nur Maulana & 75 & 80 & 10 & \\
\hline \multicolumn{4}{|c|}{ Jumlah Rata-rata } & 17,5 & \\
\hline \multicolumn{5}{|c|}{ Kelompok 5} & \\
\hline 1 & Jihan Fitrian & 75 & 75 & - & \\
\hline 2 & Aditya Panjidanni & 85 & 90 & 10 & \\
\hline 3 & Guntur Ibrahim & 85 & 90 & 10 & \\
\hline 4 & Hanny Meilani & 85 & 95 & 20 & \\
\hline \multicolumn{4}{|c|}{ Jumlah Rata-rata } & 13,3 & \\
\hline \multicolumn{5}{|c|}{ Kelompok 6} & TIM BAIK \\
\hline 1 & Arasy Akbar Witarsa & 70 & 80 & 20 & \\
\hline 2 & Muhamad Fajar K & 75 & 70 & 5 & \\
\hline 3 & Rina Nuraeni & 90 & 95 & 10 & \\
\hline 4 & Vira Firliana Oktaviani & 70 & 90 & 30 & \\
\hline \multicolumn{4}{|c|}{ Jumlah Rata-rata } & 16,25 & \\
\hline \multicolumn{5}{|c|}{ Kelompok 7} & TIM BAIK \\
\hline 1 & Mohamad Rizky & 50 & 60 & 20 & \\
\hline 2 & Mega Mulyani & 60 & 70 & 20 & \\
\hline
\end{tabular}




\begin{tabular}{|c|c|c|c|c|c|}
\hline No & Nama Siswa & $\begin{array}{l}\text { Skor } \\
\text { Awal }\end{array}$ & $\begin{array}{l}\text { Skor } \\
\text { Kuis }\end{array}$ & $\begin{array}{c}\text { Poin } \\
\text { Kemajuan }\end{array}$ & Penghargaan \\
\hline 3 & Fajar Trisna Adrian & 80 & 90 & 20 & \\
\hline 4 & Izmi Agista Noer Mauli & 65 & 60 & 5 & \\
\hline \multicolumn{4}{|c|}{ Jumlah Rata-rata } & 16,25 & \\
\hline \multicolumn{5}{|c|}{ Kelompok 8} & TIM BAIK \\
\hline 1 & Bella Holisoh & 75 & 90 & 30 & \\
\hline 2 & Arlin Oktavia & 85 & 90 & 10 & \\
\hline 3 & M. Helmidzan A & 65 & 65 & - & \\
\hline 4 & Gilang Pratama G & 65 & 70 & 10 & \\
\hline \multicolumn{4}{|c|}{ Jumlah Rata-rata } & 16,67 & \\
\hline \multicolumn{5}{|c|}{ Kelompok 9} & \\
\hline 1 & Mochamad Gilang R & 60 & 65 & 10 & \\
\hline 2 & Erik Samuel & 70 & 75 & 10 & \\
\hline 3 & Fakhri Fauzan Tajudin & 60 & 65 & 10 & \\
\hline 4 & Febiyana Wulandari & 85 & 95 & 20 & \\
\hline \multicolumn{4}{|c|}{ Jumlah Rata-rata } & 12,5 & \\
\hline
\end{tabular}

Skor ini dihitung dengan membuat rata-rata skor perkembangan anggota kelompok, yaitu dengan jumlah skor perkembangan yang diperoleh anggota kelompok dibagi dengan jumlah anggota kelompok. Sesuai dengan rata-rata perkembangan kelompok, diperoleh kategori skor kelompok seperti tercantum pada tabel berikut ini:

Tabel 8

Tingkat Penghargaan Kelompok

\begin{tabular}{cc}
\hline Rata-Rata Kelompok & Penghargaan \\
\hline 15 Point & Tim baik \\
25 Point & Tim hebat \\
30 Point & Tim super \\
\hline
\end{tabular}

Sumber: Trianto (2007:56)

Setelah memperoleh nilai rata-rata dari tiap instrumen kemudian ditapsirkan dengan kriteria sebagai berikut:

Tabel 9

Kriteria Penafsiran

\begin{tabular}{lll}
\hline No & Rata-rata Skor & Penafsiran \\
\hline 1 & $0,00-0,82$ & Sangat buruk \\
2 & $0,83-1,66$ & Buruk \\
3 & $1,67-2,49$ & Kurang baik \\
4 & $2,50-3,32$ & Cukup Baik \\
5 & $3,33-4,16$ & Baik \\
6 & $4,17-5,00$ & Sangat baik/ideal \\
\hline
\end{tabular}

Sumber: Jurnal ilmiah Kependidikan FKIP UNPAS

Data yang dikumpulkan dengan angket untuk mengetahui sejauh mana penerapan model pembelajarankooperatif tipe STAD, hasilnya dapat dilihat sebagai berikut:

a. Pembelajaran kooperatif tipe STAD pada saat presentasi pembelajaran itu menjadi menyenangkan karena suasana kelas menjadi hidup, peserta didik menjadi semangat belajar dan sangat antusias dalam mengikuti kegiatan belajar mengajar di kelas.

b. Guru dapat mengatur kegiatan belajar kelompok dengan baik yang memungkinkan siswa untuk dapat saling belajar dan mengajar, belajar disini maksudnya sesama 
peserta didik dapat saling bertukar pikiran dalam memecahkan kesulitan yang dihadapi ketika pembelajaran dan mengajar maksudnya peserta didik yang sudah mengerti dapat mengajarkan kepada peserta didik yang belum mengerti. Selain dari pada itu guru memberikan arahan pada peserta didik yang mengalami kesulitan pada saat pembelajaran.

c. Peserta didik tidak mengalami kesulitan dalam mengerjakan kuis hal ini menunjukan bahwa pembelajaran koopertaif tipe STAD dapat membantu peserta didik untuk memahami materi jurnal penyesuaian sehingga dalam mengerjakan kuis pun tidak mengalami kesulitan.

d. Peserta didik terpacu untuk saling berlomba-lomba dalam mendapatkan nilai terbaik dengan adanya pemberian skor.

e. Pemberian penghargaan kelompok membuat peserta didik menjadi rajin dalam belajar. Saling memotivasi antar sesama anggota kelompoknya, bergotong royong dan bersaing secara sehat dengan kelompok lainnya agar bisa mendapatkan penghargaan.

f. Pada saat proses belajar mengajar guru dapat menyampaikan tujuan dari pengajaran itu sendiri. Sehingga peserta didik menjadi tahu bagaimana membuat jurnal penyesuaian itu.

g. Sebelum kegiatan belajar mengajar berlangsung guru mempersiapkan bahan ajar terlebih dahulu. Bahan ajar dibuat sedemikian rupa agar membuat peserta didik tertarik belajar dan membuat peserta didik menjadi tidak malas untuk belajar. Hal ini dapat memicu peserta didik dapat semangat belajar.

h. Guru dapat menggunakan media belajar dan sumber belajar dalam melaksanakan pengajarannya. Media belajar dan sumber belajar yang digunakan dapat menunjang ketika proses belajar mengajar sehingga kegiatan belajar mengajar itu tidak membosankan dan dapat menambah peserta didik semangat dalam belajar.

i. Peserta didik yang memperhatikan guru pada saat belajar dikelas, penampilan guru dari segi berpakaian yang rapih, dalam menjelaskan materi jurnal penyesuaian sudah baik dengan menggunakan bahasa yang mudah dimengerti dan dicerna oleh peserta didik sehingga materi yang diajarkan pun dapat dipahami dan dimengerti.

j. Ketika peserta didik mengalami kesulitan dalam belajar maka seorang guru harus dapat mengarahkannya dan membantu kesulitan yang dialami oleh peserta didik itu. Misalnya peserta didik mengalami kebingungan pada saat menentukan jurnal penyesuaiannya apabila pada saat membayar premi asuransi, didebet akun beban asuransi dan dikredit kas berarti perusahaan mengunakan metode beban.

k. Guru dapat menciptakan kondisi belajar mengajar yang kondusif. Ketika seorang guru dapat disenangi dan mempunyai wibawa di hadapan peserta didik maka peserta didik dengan mudah dapat diarahkan oleh seorang guru sehingga dapat menciptakan kodisi atau suasana belajar mengajar yang kondusif

I. Pembelajaran kooperatif tipe STAD pada saat presentasi pembelajaran itu menjadi menyenangkan karena suasana kelas menjadi hidup, peserta didik menenjadi semangat belajar dan sangat antusias dalam mengikuti kegiatan belajar mengajar di kelas.

m. Guru selalu memotivasi peserta didik untuk mendorong peserta didik agar belajar aktif baik untuk kerja individual, kerja kelompok maupun mendorong hanya untuk berpikir.

n. Setelah guru memberikan tugas atau kuis guru selalu menilai hasil pekerjaan peserta didiknya pada saat proses belajar mengajar.

o. pada kegiatan awal peserta didik di data kehadirannya. Kegiatan mendata kehadiran ini adalah kegiatan yang rutin dilakukan setiap kali pembelajaran.

Dari uraian di atas maka dapat dinyatakan bahwa berdasarkan item no 6-15 efektivitas proses belajar mengajar menunjukan hasil yang baik, dari segi peserta didiknya yang mempunyai respon yang baik dengan pembelajaran model kooperatif tipe STAD sehingga kondisi pada saat proses belajar mengajar menjadi kondusif. Untuk mengetahui tingkat efektifitasnya dapat diketahui dengancara sebagai berikut: 


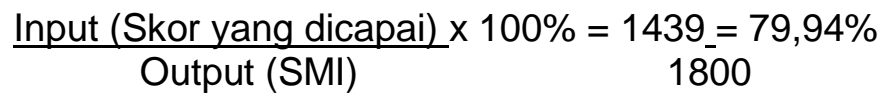

Dari perhitungan di atas diperoleh skor 79,94 yang menunjukan bahwa pembelajaran dengan menggunakan model pembelajaran tipe STAD dapat memberikan efektivitas pada proses belajar mengajar. Hal ini dapat ditunjang dengan peserta didik yang aktif pada saat kegiatan belajar mengajar berlangsung dan guru yang baik dalam pengelolaan kelas.

\section{KESIMPULAN}

Berdasarkan hasil angket yang diperoleh, pada bab ini dikemukakan kesimpulan yang dapat ditarik dan diberikan beberapa saran sebagai berikut :

1. Hasil penerapan konsep jurnal penyesuaian melalui model pembelajaran kooperatif tipe STAD melalui angket diperoleh hasil rata-rata klasikal adalah 3,94 dan berada pada kategori baik. Hal ini dapat ditunjang dengan peserta didiknya yang mempunyai respon yang baik dengan pembelajaran model kooperatif tipe STAD dan dari peneliti pun dapat menggunakan model pembelajaran tipe STAD ini dengan baik.

2. Efektivitas proses belajar mengajar pada mata pelajaran akuntansi pokok bahasan jurnal penyesuaian dengan menggunakan model pembelajaran kooperatif tipe STAD melalui angket diperoleh hasil rata-rata klasikal adalah 3,99 dan berada pada kategori baik. Kegiatan proses belajar mengajar ini menunjukan efektivitas proses belajar mengajar sebesar 79,94. Hal ini dapat di dukung dengan peserta didik yang mempunyai respon yang baik dengan pembelajaran model kooperatif tipe STAD sehingga kondisi pada saat proses belajar mengajar menjadi kondusif dan guru yang dapat mengelola kelas dengan baik.

3. Model pembelajaran kooperatif tipe STAD (Student Teams Achievement Division) dapat mengatasi kejenuhan dan kesulitan yang dialami oleh peserta didik kelas XI IPS 3 SMAN

6 Bandung. Melalui angket diperoleh hasil rata-rata klasikal adalah 3,97 dan berada pada kategori baik. Dari uraian di atas maka dapat dinyatakan bahwa dengan menggunakan model pembelajaran kooperatif tipe STAD dapat mengatasi kejenuhan dan mengatasi kesulitan yang dihadapi peserta didik dalam kegiatan belajar mengajar. Hal ini dapat didukung dengan cara guru lebih membuat peserta didik untuk aktif agar situasi kelas atau kondisi kelas menjadi hidup.

\section{DAFTAR PUSTAKA}

Arikunto, Suharsimi. 2006. Prosedur Penelitian Suatu Pendekatan Praktik. Jakarta: Rineka Cipta

Asep Syamsulbachri.. 2007. Pengantar Strategi Belajar Mengajar. Bandung :

FKIP Universitas Pasundan.

Lie, Anita. 2002. Cooperative Learning Mempraktikan Cooperative Learning Di

Ruang-ruang Kelas. Jakarta: Grasindo.

Gunawan, 2011. Kajian Model Pembelajaran Kooperatif Tipe Jigsaw Dalam Upaya Peningkatan Hasil Belajar Siswa di SMAN 18 Bandung (Studi kasus tentang pokok bahasan Jurnal Umum Kelas XI IPS 2). Universitas Pasundan Bandung: Tidak diterbitkan

Makmun A.S. Psikologi Kependidikan Perangkat Sistem Pengajaran Modul. Bandung:

Rosda

Muhubbin Syah. (2005). Psikologi Pendidikan dengan Pendekatan Baru. Bandung: PT. 
Remaja Rosda Karya.

Pradja. A.L, 2008. Modul Profesi Keguruan Bandung: Lembaga Penelitian UnPAS

Sukmadinata N.S. Landasan Psikologi Proses Pendidikan. Bandung: Rosda

Slavin, Robert E. (2009). Cooverative Learning Teori, Riset dan Praktik. Bandung: Nusa Media

Suprijono, Agus. 2012. Cooperatif Learning Teori \& Aplikasi Paikem. Yogyakarta: Pustaka Pelajar

Suryosubroto, 2009. Proses Baelajar Mengajar di sekolah. Jakarta: PT Rineka Cipta

Tim FKIP. (2009). Pedoman Penyusunan Skripsi dan Pelaksanaan Ujian Sidang SarjanaPendidikan. Bandung: FKIP Unpas.

Trianto, 2007. Model-model Pembelajaran Inovatif Berorientasi Konstruktivistik. Jakarta: Prestasi Pustaka Publisher. 